\title{
PERAN PENGAJIAN TERHADAP PERKEMBANGAN KONSEP KEBERAGAMAAN PADA DIRI REMAJA DI KOTA BANJARMASIN
}

\author{
Armiah Najla \\ UIN Antasari Banjarmasin
}

\begin{abstract}
Religious, for adults is a way of life and not just follow-up. But what about teenagers? Many psychologists say teens are investigating religion as a source of emotional and intellectual stimulation. Teens do not want to take for granted the religious material he hears. Teenagers will cultivate and then decide. In this process comes the significant roles of others who will direct the concept of religiousness in adolescents. Researchers want to see how the influence of reference groups and the environment in shaping and developing adolescent self-concept especially in adolescent religiousness.
\end{abstract}

Keywords: religious, youth, self concept, role, and study

\section{Pendahuluan}

Remaja di Kota Banjarmasin, saat ini turut mengalami imbas kemajuan dan arus globalisasi. Banyak kasus kriminal seperti narkoba, judi berkedok games offline maupun online, perkelahian dan pencurian. Belum lagi media sosial maupun budaya pop turut menghiasi kehidupan anak muda di Banjarmasin. Akibatnya perhatian akan agama menjadi berkurang. Di sisi lain, upaya pendakwah untuk tetap giat berdakwah mengajak amar ma'ruf nahi munkar juga tiada henti. Sasaran mad'unya kepada semua lapisan masyarakat termasuk anak muda. Kerapkali materi pengajian menyinggung pula masalah sosial kemasyarakatan. Tidak ketinggalan para orangtua turut pula menggandeng dan merangkul anakanaknya untuk menyimak siraman rohani berupa ceramah agama, duduk menyimak bersama buah hatinya di pengajianpengajian.

Kegiatan ceramah agama yang banyak diselenggarakan di majelis taklim-majelim, pesantren ataupun lembaga kajian agama di kota 
Banjarmasin menimbulkan ketertarikan masyarakat untuk mengikutinya, tidak terkecuali para remaja. Banyak faktor yang menyebabkan remaja ingin mengikuti kegiatan ceramah agama, di antaranya ada kesadaran dalam diri mereka untuk mendekatkan diri kepada Allah, ajakan teman-teman, atau anggota keluarganya.

Remaja menaruh minat pada agama dan mengganggap bahwa agama berperan penting dalam kehidupan. Minat pada agama antara lain tampak pada ketertarikannya membahas masalah agama, mengikuti pelajaran-pelajaran agama di sekolah dan perguruan tinggi, atau mengikuti pengajian dan ceramah di majelis taklim, lembaga keagamaan atau mesjid.

Berdasarkan pengamatan awal peneliti menganggap kegiatan ceramah agama ini sangat menarik mengingat semangat religiusitas dan nilai-nilai spiritual di kota besar khususnya di Kota Banjarmasin saat ini relatif tinggi. Kenyataan ini bisa dilihat dari banyaknya kegiatan ceramah agama yang diselenggarakan mesjid-mesjid atau pesantren-pesantren. Semangat remaja untuk mengikuti kegiatan ceramah agama di Banjarmasin ini tampak jelas manakala ada sejumlah acara keagamaan digelar. Munculnya kesadaran dari para orangtua dan remaja itu sendiri untuk mengenal lebih jauh tentang Islam sekaligus memperdalam pengetahuannya tentang agama Islam, menjadi hal yang penting. Agar remaja tidak larut dalam arus globalisasi tetapi tepat melek bahkan bisa mengukur bagaimana kadar keberagamaan sejak diri.

Oleh karena itu, peneliti tertarik untuk melihat sejauh mana peran pengajian terhadap perkembangan konsep keberagamaan pada diri remaja di kota Banjarmasin, khususnya dalam proses awal pembentuk konsep diri keberagamaannya. Konsep diri keberagamaan ini penting sebagai dasar pijakan nantinya remaja ingin mengarahkan perahu kehidupannya ke arah mana. Sikap dan perilaku keberagamaannya akan terbentuk secara stabil jika konsep dirinya telah terbentuk, meskipun masih dalam taraf awal dan dapat berubah karena faktor lingkungan dan faktor dalam dirinya. Namun konsep diri keberagamaan ini sangat menentukan bagaimana kematangan beragama remaja selanjutnya. 


\section{Pembahasan}

\section{Kerangka Pemikiran}

Gambaran mengenai pemahaman keagamaan remaja, pembentukan dan perkembangan konsep diri remaja dalam kegiatan ceramah agama dan perilaku moral remaja di masyarakat setelah mengikuti ceramah agama, dapat diteropong lewat perspektif psikologi komunikasi, utamanya konsep diri, interpersonal communications approach.

Pakar psikodlogi, Hurluck (1980:222) menjelaskan intensitas minat keagamaan dalam diri seorang individu biasanya meningkat secara gradual sejalan dengan meningkatnya usia. Peningkatan minat keagamaan ini bisa dikaitkan dengan asumsi bahwa semakin tua seseorang semakin dekat dengan kematian dan akhirat. Dalam hubungan ini kuatnya minat agama dimotivasi oleh persiapan ke kehidupan setelah kematian (pilihannya surga atau neraka).

Kuat lemahnya intensitas minat keagamaan para remaja akhir hingga dewasa awal ini dipengaruhi oleh banyak faktor antara lain: Pertama, ada tidaknya "pembiasaan" sebagai pengaruh pendidikan keagamaan sejak masa kanak-kanak, yang dapat membentuk pola perilaku keagamaan remaja. Kedua, ada tidaknya praktek keagamaan dalam lingkungan sekitar terutama teman sepergaulan atau keluarga. Jika tetangga dan sahabat seseorang banyak yang aktif beribadah, maka individu sangat mungkin akan kuat pula minatnya dalam praktek agama. Ketiga, kuat atau lemahnya persoalan yang dihadapi oleh seseorang. Kalau seseorang menghadapi kesukaran berat maka ia cenderung berminat pada agama dan menguatkan minatnya itu. Keempat, ada tidaknya tanggung jawab pendidikan agama para orang tua terhadap anak-anak. Jika orangtua mempunyai tanggung jawab yang kuat terhadap pendidikan agama bagi anak-anaknya, maka ia cenderung mempunyai minat kuat pada agama dan aktif beribadah untuk memberikan contoh pada anak-anak mereka.

Dari empat faktor yang mempengaruhi kuat lemahnya intensitas minat keagamaan para remaja akhir hingga dewasa awal ini, peneliti tertarik untuk menelaah proses pembentukan dan perkembangan konsep diri remaja dalam kegiatan ceramah agama. Dalam membentuk konsep diri remaja (yang sangat rentan dengan perubahan positif 
maupun negatif), peran agama penting sekali agar ketika remaja berada dalam lingkup interaksi sosialnya mempunyai self esteem yang kuat. Pada remaja yang sedang mencari eksistensi dan identitas diri, agama mampu menawarkan perlindungan dan rasa aman (Adam \& Gullotta, 1983:374).

\section{Konsep Diri}

Dalam interaksi sosialnya remaja memiliki kecenderungan untuk mencari minat yang sama dengan temantemannya. Kesamaan minat utamanya dalam kegiatan agama ini merupakan wujud aktualisasi remaja dalam lingkungan sosialnya. Carl Rogers menegaskan kunci aktualisasi diri adalah konsep diri. Apa yang disebut konsep diri, oleh Rogers itulah yang dinamakan Diri (Self).

Konsep diri adalah ciptaan sosial, hasil belajar kita melalui hubungan kita dengan orang lain. Konsep diri sebagian besar merupakan hasil pengalaman anak waktu kecil, yang dibentuk oleh keluarga dan orang-orang dekat lainnya termasuk kerabat. Mereka itulah yang disebut significant other.
Pada perkembangannya konsep diri manusia terus berubah dan terbentuk, sepanjang rentang kehidupan manusia, yang salah satunya dipengaruhi oleh lingkungan pergaulan (teman-teman di sekolah, perguruan tinggi atau tempat aktivitas kita lainnya). Aspek-aspek konsep diri seperti jenis kelamin, agama, kesukuan, pendidikan, pengalaman, rupa fisik kita, dan sebagainya kita internalisasikan lewat pernyataan (umpan balik) orang lain yang menegaskan aspek-aspek tersebut kepada kita, yang pada gilirannya menuntut kita berperilaku sebagaimana orang lain memandang kita.

Rogers (dalam Calhoun,1978;67) mengungkapkan konsep diri adalah pandangan diri anda tentang anda sendiri. Potret mental ini menurut Rogers memiliki tiga dimensi, yakni : 1). pengetahuan, 2). pengharapan dan 3). penilaian.

1. Pengetahuan anda tentang diri anda sendiri.

Dimensi pertama dari konsep diri adalah apa yang kita ketahui tentang diri sendiri. Dalam benak kita ada satu daftar julukan yang menggambarkan diri kita seperti usia, 
jenis kelamin, agama, kebangsaan, suku, pekerjaan dan sebagainya. Julukan seperti ini dapat diganti setiap saat, tapi sepanjang kita mengidentifikasi dengan suatu kelompok, kelompok tersebut memberi kita sejumlah informasi lain yang kita masukkan ke dalam potret diri mental kita.

2. Harapan anda mengenai diri anda.

Pada saat kita mempunyai satu set pandangan tentang siapa kita, kita juga mempunyai satu set pandangan lain yaitu tentang kemungkinan kita menjadi apa di masa mendatang (Rogers, 1959). Jadi, kita mempunyai pengharapan bagi diri kita sendiri yang terakumulasi dalam diri ideal, dimana masing-masing individu punya diri ideal yang sangat berbeda. Apapun harapan atau tujuan kita, mereka membangkitkan kekuatan yang mendorong kita menuju masa depan dan memandu kegiatan kita dalam perjalanan hidup kita. Setelah kita mencapai tujuan kita, hampir pasti akan muncul cita-cita lain.
3. Penilaian tentang diri anda sendiri.

Dimensi ketiga konsep diri adalah penilaian kita terhadap diri kita sendiri. Kita berkedudukan sebagai penilai tentang diri kita sendiri setiap hari, mengukur apakah kita bertentangan dengan (1) "sayadapat-menjadi apa", yaitu pengharapan kita bagi kita sendiri, dan (2) "saya-seharusnya-menjadi apa"” yaitu standar kita bagi diri sendiri (Erikson, E.H, 1964).

Sedangkan elemen pada setiap dimensi utama dari persepsi diri adalah: (1) kemampuan diri, (2) karakteristik diri atau sifat, (3) status, (4) peran, (5) milik, (6) tujuan, (7) rasa takut sehubungan dengan karakteristik diri, dan (8) rasa bersalah sehubungan dengan karakteristik diri.

Secara teori konsep diri yang terbentuk ada dua jenis yakni konsep diri negatif dan konsep diri positif.

1). Konsep diri negatif yang di bagi menjadi dua, yakni :

a). Pandangan seseorang tentang dirinya sendiri benar-benar tidak teratur, ia tidak mengetahui siapa dirinya, apa kekuatan dan kelemahannya, atau apa yang dia 
hargai dalam hidupnya. Kondisi ini umum dan normal di antara para remaja. Konsep diri mereka kerapkali menjadi tidak teratur untuk sementara waktu dan ini terjadi pada saat transisi dari peran anak ke peran orang dewasa (Erikson, 1968).

b). Tipe kedua dari konsep diri negatif hampir merupakan lawan dari konsep diri negatif yang pertama. Di sini konsep diri terlalu stabil dan terlalu teratur (dengan kata lain KAKU). Penyebabnya mungkin karena didikkan orangtuanya yang terlalu keras, sehingga individu tersebut menciptakan citra diri secara perfeks (ia tidak mengizinkan adanya penyimpangan dari seperangkat hukum yang dalam pikirannya merupakan cara hidup yang tepat).

Pada kedua tipe konsep diri negatif, informasi baru tentang diri hampir pasti menjadi penyebab kecemasan, rasa ancaman terhadap diri. Tidak satupun dari kedua konsep diri cukup bervariasi untuk menyerap berbagai macam informasi tentang diri. Setiap hari pikiran manusia mengalami pemilihan yang ketat tentang berbagai macam dorongan, di ingatan, dan tanggapan, yang semuanya itu merefleksi pada diri.

2). Konsep diri positif.

Orang yang memiliki konsep diri positif adalah orang yang dapat memahami dan menerima sejumlah fakta beragam mengenai dirinya. Konsep diri positif ini cukup luas untuk menampung seluruh pengalaman mental seseorang, evaluasi tentang dirinya sendiri menjadi positif. Dia dapat menerima dirinya sendiri apa adanya. Hal ini tidak berarti bahwa dia tidak pernah kecewa terhadap dirinya sendiri atau kegagalan mengenali kesalahannya sebagai suatu kesalahan. Namun ia merasa tidak perlu meminta maaf untuk eksistensinya. Dengan menerima dirinya sendiri, dia juga dapat menerima orang lain. Seperti yang dijelaskan Erich Fromm (1974), cinta pada diri sendiri adalah prasyarat untuk dapat mencintai orang lain.

Bidang konsep diri positif menjadi modal yang lebih berharga 
dibanding daerah lain. Tidak seperti orang yang konsep diri negatif yang membangun dalam suatu benteng pertahanan, orang yang berkonsep diri positif dapat tampil ke depan secara bebas. Baginya hidup adalah suatu proses penemuan. Ia akan bertindak dengan berani dan spontan serta memperlakukan orang lain dengan hangat dan hormat. Konsep diri yang positif seperti halnya konsep diri negatif, adalah bagian dari hubungan yang melingkar.

\section{Pembentukan dan Perkembangan Konsep Diri}

Seorang individu dalam interaksinya mampu mengenal siapa dirinya baik sebagai individu maupun sebagai anggota kelompok. Kita sadar bahwa kita manusia karena orang-orang di sekeliling kita menunjukkan kepada kita lewat perilaku verbal dan nonverbal mereka bahwa kita manusia. Bahkan kita pun tidak akan pernah menyadari nama kita adalah si "Fulan", bahwa kita adalah perempuan, laki-laki, pintar atau menyenangkan, bila tidak pernah ada orang-orang di sekitar kita yang menyebut kita demikian. Melalui komunikasi dengan orang lain kita belajar bukan saja mengenai siapa kita, namun juga bagaimana kita merasakan siapa kita. Pandangan itu bisa kita peroleh melalui proses komunikasi, karena salah satu fungsi komunikasi adalah untuk membangun konsep diri kita dan aktualisasi diri (Mulyana, 2001:5). Komunikasilah yang memungkinkan individu membangun suatu kerangka rujukan dan menggunakannya sebagai panduan untuk menafsirkan situasi apapun yang ia dihadapi.

Dalam kegiatan ceramah agama atau pengajian, remaja berperan sebagai orang yang menerima pesan-pesan keagamaan yang antara lain berisi tentang nilai-nilai kehidupan dunia baik dalam konteks individu maupun kemasyarakatan dan nilai kehidupan akhirat. Pengajian di mesjid-mesjid dan pesantren dapat dikatakan sebagai salah satu wadah pembentukan konsep diri keagamaan remaja. Dalam hal ini peneliti mengamati proses pembentukan dan perkembangan konsep diri remaja terutama pemahaman dan cara pandangnya atas nilai-nilai keagamaannya baik sebelum mengikuti, 
saat mengikuti, dan setelah mengikuti ceramah agama.

Pendekatan yang ingin diambil adalah pendekatan psikologi komunikasi khususnya pada kajian komunikasi interpersonal yang di dalamnya membahas mengenai konsep diri. Ketertarikan mengenal lebih mendalam lagi mengenai nilai-nilai agama dalam konteks komunikasi interpersonal menyebabkan kita mengerti bagaimana pandangan keagamaan kita selama ini, untuk kemudian didialogkan dengan kondisi internal diri dan dari hasil interaksi kita dengan orang lain. Di sini yang lebih ditekankan adalah pengalaman spritual remaja ketika mengikuti pengajian.

Joseph. A. Devito dalam bukunya The Interpersonal Communication Book, mendefinisikan komunikasi interpersonal sebagai, "Proses pengiriman dan penerimaan pesan-pesan antara dua orang atau di antara sekelompok kecil orangorang, dengan beberapa efek dan beberapa umpan balik seketika" (Effendy, 1993:60). Sedang Verderber (1986) mengungkapkan komunikasi interpersonal merupakan suatu proses interaksi dan pembagian makna yang terkandung dalam gagasan-gagasan maupun perasaan. Ketika orang berkomunikasi, maka yang terjadi adalah suatu proses transaksional yang dapat diartikan: (1) siapa yang terlibat dalam proses komunikasi saling membutuhkan tanggapan demi suksesnya komunikasi itu; (2) komunikasi melibatkan interaksi dari banyak unsur. Ia dipengaruhi oleh nilai-nilai yang dianutnya, kebudayaan, lingkungan, pengalaman, pekerjaan, jenis kelamin, minat, pengetahuan dan sikap. Keseluruhan wilayah yang mengitari, baik pengirim maupun penerima, adalah situasi dan kondisi yang sering disebut konteks. Pada saat yang sama dapat terjadi gangguan eksternal, internal, ataupun semantik.

Dari beberapa definisi di atas, esensi yang melekat pada komunikasi interpersonal terangkum dalam karakteristiknya, seperti yang dikemukakan Liliweri (1994:3) sebagai berikut: (1) terjadi dimana dan kapan saja. Gambaran ini menunjukkan bahwa manusia tidak dapat terhindar dari komunikasi. Karena itu, komunikasi hadir dalam masyarakat tradisional ataupun masyarakat modern. (2) proses yang berkesinambungan antara masa lalu, 
kini, dan sekarang. (3) punya tujuan tertentu secara implisit maupun eksplisit. (4) menghasilkan hubungan timbal balik, menciptakan serta mempertukarkan makna yang kemudian berkembang menjadi relasi dan transaksional. (5) terkandung prinsip bahwa pribadi yang satu mempelajari hakikat pribadi yang lain. (6) meramalkan sesuatu, artinya ada harapan hasil yang memuaskan keduanya. (7) komunikasi interpersonal sering dan dapat dimulai dengan melakukan kesalahan.

Pembentukan dan perkembangan konsep diri remaja mengenai pandangan dan nilai-nilai keagamaannya ini bisa tercipta melalui proses komunikasi interpersonal dalam bentuk pengajian dan ceramah agama. Pembentukan dan perkembangan konsep diri remaja bisa efektif jika memperhatikan faktor-faktor yang mempengaruhinya, yakni unsurunsur yang terkait dalam komunikasi seperti komunikator (penceramah), pesan (pesan keagamaan), media komunikasi, komunikan (peserta pengajian) dan efek komunikasi (kognisi, afeksi, konasi). Dalam pendekatan humanistic (khususnya interaksi simbolik), efektif tidaknya komunikasi interpersonal yang berlangsung bisa mengacu pada lima kualitas berikut, yakni: keterbukaan (openness), empati (emphaty), sikap mendukung (supportiveness), sikap positif (positiveness) dan kesetaraan (equality). (Devito, 1997: 259).

\section{Hasil Penelitian dan Analisis}

Remaja dalam penelitian kali ini dikategorikan pada usia 13 sampai 18 tahun. Di mana masa remaja ini, sebagai peralihan dari masa anak-anak ke masa dewasa. Pada masa remaja, biasanya anak tidak mau lagi diperlakukan sebagai anak-anak, tetapi dilihat dari pertumbuhan fisiknya ia belum dikatakan orang dewasa.

Dalam hal keberagamaannya, banyak pakar psikolog menyatakan remaja menyelidiki agama sebagai suatu sumber dari rangsangan emosional dan intelektual. Remaja tidak ingin menerima begitu saja materi keagamaan yang ia dengar. Remaja akan mengolah kembali baru kemudian memutuskan bentukbentuk pemikiran dan praktek keberagamaannya. Dalam proses inilah muncul peran-peran significant others yang akan mengarahkan konsep keberagamaan dalam diri remaja. 
Significant others, dalam penelitian ini adalah kelompok-kelompok majelis taklim atau pengajian yang ada di kota Banjarmasin, yang sering didatangi remaja untuk menyimak materi-materi ceramah agama. Di samping pengajian keberadaan orangtua dan teman sebanya juga turut berperan dalam pembentukan konsep keberagamaan pada diri remaja. Pengajian yang ada di Banjarmasin cukup banyak dan bervariasi, di antaranya pengajian guru Zuhdi, majelis taklim Supian, Guru Haderawi, Guru Zainuddin Rais, pengajian ustadz Rasyid Ridha, pengajian Guru Syaifuddin Juhri (Majelis Taklim Bani Ismail), Majelis Taklim Wal Maulid Alkhuluqul Hasan, pengajian guru Hafiz Anhsari, Guru Hamdani, dan sebagainya. Dari pengajian yang kerapkali hadir di kota Banjarmasin, pengajian Guru Zuhdi berdasarkan pengamatan peneliti dipenuhi lebih banyak para remaja dibandingkan pengajian-pengajian oleh guru-guru yang lain. Hal ini disebabkan gaya penyampaian beliau yang mudah diterima oleh semua kalangan, termasuk para remaja. Materi yang disampaikan dekat dengan persoalan hidup dan kehidupan masyarakat Banjarmasin.
Berikut profil guru Zuhdi yang peneliti peroleh dari situs cinta dan rindu.

Guru Zuhdi lahir 10 Februari 1972 dan anak dari KH. Muhammad (pimpinan Al Falah setelah KH. Tsani), $\mathrm{KH}$. Muhammad adalah sahabat Abah Guru Sekumpul dan juga murid dari KH. Anang Sya'rani Arief. Menurut kisah bahwa Abah Guru pernah sekelambu lawan KH. Muhammad. sekarang Umur Guru Zuhdi kira-kira 30-40 an. Beliau membuka Majlis, dulunya tidak sebesar seperti sekarang dan Pengajian Kitab awal-awal yang beliau bacakan dari catatan tangan Majlis Abah Guru. Para Jamaah yang hadir di Majlis sidin kadang2 terobati Kerinduan kepada Majlis Abah Guru Sekumpul karena Kitab, Cara Majlis, Isi kajian dalam Majlis, Gaya bicara dan penjelasan, Tamu2 beliau dan Tamu yang hadir diantara para habaib yang hadir di majlis dan Silaturrahmi ke rumah Guru Zuhdi sangat mirip dengan Abah Guru Sekumpul meskipun ane dan yang lain juga tidak berani menyamakan kedudukan dan pangkat Abah Guru Sekumpul dan tidak akan ada yang menyamainya.

Majlis Pengajian malam sabtu dilaksanakan di rumah kediaman Tuan Guru Zuhdi di Jalan Masjid Jami (Belakang mesjid jami), Kec. Banjarmasin Utara. Sepintas, dari jalan raya memang tidak tampak, karena tertutup perkampungan. tapi 
begitu masuk (lebih kurang 400m), terasalah denyut kehidupan majlis pengajian.dan malam minggu pengajian diadakan di mesjid jami.

Majlis yang menggunakan metode tradisional, di mana sang guru membacakan materi pelajaran dari suatu kitab, dan para santri duduk mengelilinginya sambil membubuhkan catatan di sanasini dengan bimbingan sang kyai (dabit).

Kebersihan lingkungannya tampak sangat terjaga. Agak masuk ke dalam, ada sebuah rumah kecil berwarna cream. Di situlah KH. Ahmad Juhdianoor tinggal, tokoh muda ulama kharismatik banjarmasin yang sangat digemari kalangan tua dan muda saat ini (Ahmad Rifky

Fauzan: http://www.berkahnya sholawat.com Di akses Tanggal 23 Oktober 2017).

Peneliti menilai pengajian Guru Zuhdi lebih banyak berperan dalam pembenntukan konsep keberagamaan pada diri remaja, karena kepribadian, materi dan gaya penyampaian guru Zuhdi yang kharismatik, santai namun santun. Ketika menyimak dakwah guru Zuhdi baik hadir langsung pada pengajian maupun mendengarkan rekaman ceramah beliau, para remaja dapat belajar agama, sekaligus memperdalam ilmu agama serta meningkatkan keimanan dan ketakwaan umat kepada Allah Swt.

Keberadaan pengajian tersebut rutin dilaksanakan secara periodic (per minggu). Para jamaahnya berdatangan dari pelbagai sudut kota di Banjarmasin, bahkan sampai ke hulu sungai dan propinsi lain di Kalimantan. Pada acara hari besar keagamaan, dapat mencapai ribuan orang. Kategori usia jamaah sangat bervariasi, mulai dari anak-anak hingga usia lanjut. Para ibu-ibu dan Bapak-bapak, remaja (kaum muda), turut hadir mendengarkan siraman rohani pada "Guru-Guru".

Dalam penelitian ini menunjukkan, keberadaaan kelompok rujukan dalam pembentukan konsep diri remaja dalam aktivitas keberagamaannya menunjukkan arti penting. Faktor kelompok rujukan atau faktor lingkungan masyarakat dan lingkungan pergaulan mempunyai pengaruh yang cukup besar terhadap pembentukan konsep diri remaja dalam memotivasi mereka untuk aktif ke pengajian. Ajakan teman dan keluarga memiliki peran penting untuk memperkuat motivasi awal yang sudah remaja miliki dalam dirinya. Artinya niat dalam hati untuk senantiasa mempertebal 
keimanan dan mengisi waktu pada halhal yang bermanfaat didorong oleh kelompok rujukan dan lingkungan sekitar turut memperkuat konsep diri remaja ke arah yang lebih baik.

Berikut pernyataan para pengelola remaja masjid khusus akhwat yang ada di kota Banjarmasin.

Terima kasih kepada adik-adik remaja putri yang kemarin telah menyempatkan waktu untuk menghadiri acara pengajian kita yang keren ini. Terima kasih untuk semangat kalian yang punya keinginan untuk maju dan berubah. Inshaa Allah kita akan melanjutkan kegiatan positif ini untuk seterusnya. Semoga semangat kalian akan semakin berkobar dan bisa menularkan semangat yang sama kepada teman-teman yang kemarin belum berkesempatan hadir supaya lain kali bisa ikut hadir. Semoga masukan dan harapan kalian juga bisa segera terwujud. Aaminn. Kami sebagai orang tua hanya bisa memfasilitasi dan mensupport saja selebihnya kalian sendirilah yang akan menentukan dan memutuskan.

Kegiatan pengajian-pengajian keagamaan biasanya ditujukan untuk meningkatkan keimanan, penghayatan dan pengamalan agama seseorang. Kegiatan tersebut sebagai usaha untuk memantapkan keyakinan dan kesadaran beragama dalam memperkokoh keagamaan dan berperan serta untuk membina kedisiplinan dalam menjalankan keagamaan. Remaja di Banjarmasin dalam wawancara mengakui:

"Menambah pemahaman tentang ilmu agama. Emang benar di sekolah kami sudah mendapatkan pelajaran agama. Apalagi bagi teman-teman yang sekolahnya khusus di sekolah Islam, pasti tidak diragukan lagi kepandaiannya dalam hal ilmu agama. Namun ketika pengajian itu dilakukan di lingkungan tempat tinggal, tetap ada hal lain yang bisa saya temukan, misalnya suasana. Beda ya belajar di sekolah dengan di masjid yang lebih santai, sambil makan snack, sambil bercandaan. Relax." (Ariyannor; wawancara tanggal 30 September 2017)

Pengetahuan agama yang diberikan secara langsung, sekaligus dalam bentuk praktek oleh kelompok rujukan yang remaja tersebut telah percayai, mengakibatkan proses penerimaan pesan dalam bentuk materi agama lebih efektif. Arrtinya, remaja lebih memiliki sikap keterbukaan akan masuknya informasi Islami yang secara suka rela ia pahami dan praktekkan, tanpa 
ada paksaan dan ia juga lebih enjoy menjalankan ibadah, karena teman-teman sebayanya juga melakukan hal yang sama. Kebersamaan dengan kawan sebaya menyebabkan situasi dan pendalaman keberagamaannya menjadi kuat.

Hal ini sesuai dengan teori yang telah peneliti gagas sebelumnya mengenai faktor pembentuk konsep keberagamaan remaja keterbukaan, empati, sikap mendukung, sikap positif dan kesetaraan dari Devito (1997: 259). Di mana, kualitas keterbukaan mengacu pada sedikitnya tiga aspek dari komunikasi antar persona. Pertama, komunikator antar persona yang efektif harus terbuka kepada orang yang diajaknya berinteraksi. Harus ada kesediaan untuk membuka dirimengungkapkan informasi yang biasanya disembunyikan, sebatas pengungkapan diri itu santun. Aspek keterbukaan yang kedua mengacu pada kesediaan komunikator untuk bereaksi secara jujur terhadap stimulus yang datang. Aspek ketiga, menyangkut "kepemilikan" perasaan dan pikiran (Bochner \&Kelly, 1974). Terbuka dalam pengertian ini adalah mengakui bahwa perasaan dan pikiran yang kita lontarkan adalah memang "milik" kita dan bertanggung jawab atasnya. Cara terbaik untuk menyatakan tanggung jawab ini adalah dengan pesan yang menggunakan kata saya (kata ganti orang pertama tunggal).

Berempati, yakni merasakan sesuatu seperti orang yang mengalaminya ---berada di kapal yang sama dan merasakan perasaan yang sama dengan cara yang sama. Orang yang empatik mampu memahami motivasi dan pengalaman orang lain, perasaan dan sikap mereka, serta harapan dan keinginan mereka untuk masa datang. Pengertian yang empatik ini akan membuat seseorang lebih mampu menyesuaikan komunikasinya.

Sikap mendukung, yang erat kaitanya dalam proses hubungan antarpersona yang efektif. Komunikasi yang terbuka dan empatik tidak dapat berlangsung dalam suasana yang tidak mendukung. Kita memperlihatkan sikap mendukung dengan bersikap (1) deskriptif bukan evaluatif, (2) spontan, bukan strategic dan (3) provisional bukan sangat yakin. Suasana yang bersifat deskriptif dan bukan evaluatif membantu terciptanya sikap mendukung. 
Komunikasi yang bernada menilai sering membuat kita defensif. Pada umumnya, suasana evaluatif membuat orang lebih defensif daripada dalam suasana deskriptif. Gaya spontan membantu menciptakan suasana mendukung. Orang yang spontan dalam komunikasinya dan terus terang serta terbuka dalam mengutarakan pikirannya, biasanya bereaksi dengan cara yang sama, terus terang, dan terbuka. Sebaliknya, bila kita merasa seseorang menyembunyikan perasaannya yang sebenarnya bahwa dia mempunyai rencana atau strategi tersembunyi kita bereaksi secara defensif. Bersikap provisional artinya bersikap tentative dan berpikiran terbuka serta bersedia mendengar pandangan yang berlawanan dan bersedia mengubah posisi jika keadaan mengharuskan hal ini membantu dalam menciptakan suasana mendukung (suportif).

Sikap Positif. Kita mengkomunikasikan sikap positif dalam komunikasi antarpersona dengan sedikitnya dua cara: (1) menyatakan sikap positif dan (2) secara positif mendorong orang yang menjadi teman kita berinteraksi. Sikap positif mengacu pada sedikitnya dua aspek dari komunikasi antarpersona. Pertama, komunikasi antarpersona terbina jika orang memiliki sikap positif terhadap diri mereka sendiri. Orang yang merasa negatif terhadap diri sendiri selalu mengkomunikasikan perasaan ini kepada orang lain yang selanjutnya akan mengembangkan perasaan negatif yang sama. Sebaliknya orang yang merasa positif terhadap diri sendiri mengisyaratkan perasaan ini kepada orang lain, yang selanjutnya akan merefleksikan perasaan positif ini. Kedua, perasaan positif untuk situasi komunikasi pada umumnya sangat penting untuk interaksi yang efektif. Tidak ada yang lebih tidak menyenangkan ketimbang berkomunikasi dengan orang yang tidak menikmati interaksi atau tidak bereaksi secara menyenangkan terhadap situasi atau suasana interaksi. Reaksi negatif terhadap situasi ini membuat orang merasa mengganggu dan komunikasi segera akan terputus.

Sikap positif dapat dijelaskan lebih jauh dengan istilah Stroking (dorongan), dimana dorongan ini dipandang sangat penting dalam analisis transaksional dan dalam interaksi 
antarmanusia secara umum. Perilaku mendorong menghargai keberadaan dan pentingnya orang lain. Perilaku ini berlawanan bertentangan dengan ketidakperdulian. Dorongan dapat verbal, seperti mengutarakan secara terus-terang, atau nonverbal seperti senyuman, tepukan di bahu, atau acungan jempol. Dorongan positif umumnya berbentuk pujian atau penghargaan dan terdiri atas perilaku yang biasanya kita harapkan, kita nikmati dan kita banggakan. Dorongan positif ini mendukung intrapribadi kita dan membuat merasa lebih baik. Sebaliknya, dorongan negatif, bersifat menghukum dan menimbulkan kebencian.

Keberadaan kelompok rujukan dan significant others ini bisa ditemui peneliti, manakala remaja asyik mendiskusikan topik-topik dan materi pengajian yang telah ia saksikan. Ada proses pendalaman dan pengayaan materi (muhadarah) yang akhirnya memperkuat konsep diri keberagamaan remaja.

"Uthinya juga pasti berbeda. Mereka boleh dibilang paham dunia kami, dunia anak muda, sehingga mereka bisa lebih memahami dan mengerti kami karena seusia dan pastinya lebih mudah karena tidak jauh dari tempat tinggal." (Suhartini, wawancara tanggal 23 September 2017).

Peneliti menilai pendekatan personal yang dilakukan para pembimbing (uthi) dalam diskusi dan pendalaman materi yang dilakukan, telah efektif mendukung percepatan kemauan dan keinginan para muslimah untuk mengetahui lebih dalam tentang topictopik yang ia tanyakan. Kesetaraan (Equality) dalam komunikasi antarpersona akan lebih efektif bila suasananya setara. Artinya harus ada pengakuan masing-masing pihak samasama bernilai dan berharga, dan bahwa masing-masing pihak mempunyai sesuatu yang penting untuk disumbangkan.

Dalam suatu hubungan antarpersona yang ditandai oleh kesetaraan, ketidaksependapatan dan konflik, lebih dilihat sebagai upaya untuk memahami perbedaan yang pasti ada ketimbang sebagai kesempatan untuk menjatuhkan pihak lain. Kesetaraan tidak mengharuskan kita menerima dan menyetujui begitu saja semua perilaku verbal dan nonverbal pihak lain.

Kesetaraan berarti kita menerima pihak lain, atau menurut istilah Carl 
Rogers, kesetaraan meminta kita untuk memberikan "penghargaan positif tidak bersyarat" kepada orang lain. Dalam proses komunikasi ini perlu diperhatikan aspek homophily dan heterophily yang sangat mempengaruhi keefektifan komunikasi.

\section{Hubungan yang homophily}

berarti komunikator dengan komunikan terdapat banyak persamaan, misalnya yang berkaitan dengan nilai, pendidikan, status sosial dan sebagainya. Sebaliknya yang heterophily, apabila di antara pihakpihak yang berkomunikasi memiliki ciriciri (karakteristik komunikan) yang berbeda-beda. Komunikasi akan lebih efektif apabila hubungan yang terjalin antara komunikator dan komunikan bersifat homophily. Apabila ingin meningkatkan efektivitas hubungan komunikasi yang bersifat homophily, maka perlu dipergunakan komunikator (dalam hal ini uthi atau ustadz yang berasal dari lingkungan jamaahnya sendiri. Karena ia memiliki ciri-ciri yang sama dengan jamaahnya, antara lain menggunakan bahasa yang sama, adat yang sama, dan sebagainya. Dalam praktek dakwah Rasulullah-pun berlaku hal demikian. Sabda Nabi SAW, "berbicaralah dengan manusia sesuai dengan tingkat akal pikiran atau kecerdasannya. (HR. Muslim). Dan QS. 26: 214, "Dan peringatilah anggota keluargamu yang dekat.”

Pengayaan dalam perkembangan konsep diri remaja lewat pengajian yang rutin ia datangi diasumsikan akan menghasilkan kematangan beragama. Pencapaian tingkat stabilitas tertentu bagi perkembangan rohani disebut istilah kematangan (maturity). Kematangan dalam beragama. yaitu kemampuan seseorang untuk memahami, menghayati serta mengaplikasikan nilai-nilai luhur agama yang dianutnya dalam kehidupan sehari-hari. Ia menganut suatu agama karena menurut keyakinannya agama tersebutlah yang terbaik, maka ia berusaha menjadi penganut yang baik. Keyakinan itu ditampilkannya alam sikap dan tingkah laku keagamaan yang mencerminkan ketaatan terhadap agama (Jalaluddin,2001:117, 119).

Kematangan beragama remaja yang terbentuk dari hasil olahan konsep diri beragama yang baik, akan dapat menentukan berhasil tidaknya remaja tersebut untuk menjalani fase-fase kehidupan remaja selanjutnya. 
Pembentukan moral atau kepribadian dan mental yang baik taat dan tunduk pada aturan dan kehendak llah SWT adalah usaha penyelamatan diri yang paling tepat untuk menuju kedamaian dan kesejahteraan, baik untuk dirinya maupun masyarakat lingkunganya.

Hasil dari kematangan beragama remaja ini bisa dilihat dalam perubahan sikap dan sifat menjadi lebih baik dari sebelumnya. Misalnya sholatnya lebih khusyu dan tepat waktu. Tadarusnya lebih lama. Rasa cinta dan kasih sayang terhadap orang-orang terdekat lebih tulus. Rasa empati dan perduli terhadap lingkungan lebih peka dan sebagainya. Bagi anak remaja yang mulai beranjak dewasa sangat diperlukan adanya pemahaman pendalaman serta ketaatan terhadap ajaran agama yang dianutnya. Dalam hal ini dilaluinya lewat proses pembentukan dan perkembangan konsep diri keagamaannya. Dalam kenyataan sehari-hari ditunjukkannya lewat perilaku beragamanya, misalkan ia akan rajin shalat, bahkan melakukan ibadah sunnah seperti puasa sunnah, dan sebagainya.

Glock dan Star menyatakan bahwa keberagamaan seseorang pada dasarnya lebih menunjukkan kepada proses internalisasi nilai-nilai agama yang kemudian menyatu dalam diri individu dan membentuk pola fikir sehari-hari (Rosmanah, 1995:68). Orang yang telah mengalami kematangan beragama atau kedewasaan beragama akan memegang teguh keimanannya, dan diwujudkannya dalam kehidupan seharihari dengan penuh tanggung jawab. Hal ini sering dibarengi dengan pengetahuan keagamaan yang cukup mendalam. Biasanya orang yang telah matang beragama ditunjukkan dengan kesadaran dan keyakinan yang teguh, karena menganggap benar agama dianutnya dan ia perlukan dalam hidupnya.

Jika kematangan beragama tersebut telah ada dalam diri seseorang, segala perbuatan dan tingkah laku keagamaannya senantiasa dipertimbangkan betul-betul dan dibina atas rasa tanggung jawab, bukan atas dasar peniruan semata.

\section{Simpulan}

Dapat diambil kesimpulan bahwa pengajian agama telah berperan dalam memberikan acuan awal pembentukan konsep keberagamaan remaja. Pada 
perkembangan konsep diri lanjutan, para remaja ini akhirnya memiliki kemantapan berpikir, bersikap dan bertindak lewat pelaksanaan ibadah-ibadah wajib maupun sunnah yang ia jalankan atas dasar kesadaran beragamanya sendiri, bahkan ia sukarela melakukannya secara rutin. Hal ini menjadi pegangan hidupnya kelak jika ia dewasa.

Dalam Islam sendiri sudah memuat ajaran-ajaran yang dapat dijadikan pedoman dan peringatan bagi umatnya. Mereka yang memiliki dasar dan pengetahuan yang cukup, akan tertanam dalam dirinya nilai-nilai agama senantiasa mempertimbangkan setiap tindakannya, bertentangan dengan ajaran agama atau tidak, dapat melihat mana sisi positif dan mana sisi negatifnya apabila melakukan suatu tindakan.

Jadi seseorang yang mempunyai tingkat kematangan beragama akan berprilaku hati-hati dalam hidupnya agar tidak betentangan dengan ajaran agama. Semakin tinggi tingkat kematangan beragama atau pengetahuan agama seseorang maka semakin besar pertimbangan - pertimbangan yang sifatnya religius dalam merespon perkembangan dan perubahan zaman.
Semoga lewat pembentukan dan perkembangan konsep diri yang kuat tentang akidah beragama yang ia dapatkan lewat pelbagai pengajian keagamaan, akan memperkuat bahkan mematangkan sikap keberagamaan remaja lebih kokoh lagi, sehingga manakala memasuki usia dewasa akan semakin mantap keberagamaannya.

\section{Daftar Pustaka}

Adam, G.R. \& Gullotta, T.,1983, Adolescent Life Experience, Brooks/Cole Publishing Co., Monterey, California.

Ahmad

Rifky

Fauzan: http://www.berkahnya sholawat.com Di akses Tanggal 23 Oktober 2017).

Allport, Gordon W., 1950, The Individual and His Religion: A Psychological Interpretation, New York: MacMillan.

Burn, R.B., 1993, Konsep Diri: Teori, Pengukuran, Perkembangan dan Perilaku, Arcan, Jakarta.

Calhoun James F. \& Acocella. J.R., 1978, Psikologi tentang Penyesuaian dan Hubungan Kemanusiaan, Edisi ketiga, (terjemahan Ny. R.S. Satmoko), IKIP Press, Semarang.

Chaedar A. Alwasilah, 2002, Pokoknya Kualitatif, PT Kiblat Buku Utama, Jakarta. 
Devito.A. Joseph., 1997, Komunikasi Antar Manusia, Professional Books, Jakarta.

Erikson, E.H, 1964, Childhood and Society. (Rev.Ed), Norton, New York.

Fisher, B. Aubrey, 1986. Teori-teori Komunikasi. Penerj. Soehono Trimo, Remaja Rosdakarya, Banjarmasin.

Hurluck, Elizabeth B., 1980, Psikologi Perkembangan, Suatu Pendekatan Sepanjang Rentang Kehidupan, Edisi Kelima, Erlangga, Jakarta.

Jalaluddin, 2001, Psikologi Agama, Rajagrafindo Persada, Jakarta.

James, William, 1902, The Varieties of Religious Experience: A Study in Human Nature, Modern Library, New York.

Krech, David, Crutchfield, Richard S., and Ballachey, Egerton L., 1962, Individual in Society; A Text Book of Sosial Psychology, McGraw-Hill Kogakusha, LTD., California, USA, 1962.

Liliweri, Alo., 1994, Perspektif Teoritis Komunikasi Antar Pribadi, Suatu pendekatan ke arah
Psikologi Sosial Komunikasi, Citra Aditya Bakti, Banjarmasin.

Manah Rosmanah, 1995, Hubungan Religiusitas dan Pola Asuh Islami dengan Emosional Question, Tesis, Fakultas Psikologi UGM, Yogyakarta.

Mantidale, Don., 1960, The Nature and Types of Sociological Theory, Boston, Hougnton Mofflin Co.

Monk, Robert, C., dkk, 1979, Exploring Religious Meaning Prentice, Hall Internatinal Inc. London.

Mulyana, Deddy, 2001, Ilmu Komunikasi Suatu Pengantar, Remaja Rosda Karya, Bandung.

Rakhmat, Jalaluddin, 1992, Psikologi Komunikasi, Remaja Rosda Karya, Banjarmasin.

Sarlito, Sarwono, W., 2001, Psikologi Remaja, RajaGrafindo Persada, Jakarta.

Soeprato, Riyadi, 2002. Interaksionisme Simbolik, Pustaka Pelajat, Yogyakarta.

Verderber, K.S. \& R.F. Verderber, 1989, Inter-act:Using Interpersonal Communication Skills, Wadsworth, Belmont CA. 